Brit. F. vener. Dis. (1967), 43, 53.

\title{
MEDICAL PROFESSIONAL SECRECY WITH SPECIAL REFERENCE TO VENEREAL DISEASES* ${ }^{*}$
}

\author{
BY \\ W. K. BERNFELD \\ Welsh Hospital Board, United Cardiff Hospitals
}

\section{The Duty of Secrecy}

The moral duty of secrecy has been accepted by doctors since the time of Hippocrates, but is it also a legal obligation?

"There is no English reported case which decides directly that there is a legal duty of confidence on medical men. There is, however, a Scottish case in which a medical man was sued for breach of confidence" (Levitt, 1953).

That was in $1851:$ A doctor reported to a minister of a kirk that a child born to the wife of an elder 6 months after the marriage of his parents was fully developed. As a result, the elder was expelled. The doctor was successfully sued for damages for breach of an implied condition of secrecy in his contract with the elder (Kitchin, 1941 ; Levitt 1953).

\section{The Duty of Disclosure}

Various acts of Parliament, such as the Registration, Public Health, and Infectious Disease Notification Acts, have progressively encroached upon medical secrecy in the public interest.

Other "limits of the duty of non-disclosure" have been discussed in the British Medical fournal (1920b), and by Gordon, Turner, and Price (1953), Simpson (1962, 1964), Polson (1965), Speller (1965), and others. Experts do not always agree on how to deal with situations where the confidence of the patient and the interest of the community are in conflict.

There is no doubt, however, that in British courts the doctor can be compelled to tell, as there is no medical privilege in this country. The first formal announcement of the common law rule of testimonial compulsion occurred in the trial of the Duchess of Kingston in 1776, when the Earl of

\footnotetext{
* Received for publication August 2, 1966

$t$ An earlier version of this paper was awarded a C. H. Milburn Prize by The British Medical Association. A further version was read to a meeting of the MSSVD in Bristol on May 21, 1966.
}

Mansfield, in his office as Lord High Steward at the trial, ruled that a surgeon had no privilege (deWitt, 1958).

Lord Denning, in the contempt cases concerning two journalists required to reveal a source of information, said in 1963:

"The only profession that I know which is given a privilege from disclosing information to a court of law is the legal profession, and then it is not the privilege of the lawyer but of his client. Take the clergyman, the banker or the medical man. None of these is entitled to refuse to answer when directed to by a judge" (Speller, 1965).

Opposition to the common law rule of testimonial compulsion was expressed by $\mathrm{Mr}$ Justice Buller in 1792:

"There are cases to which it is much to be lamented that the law of privilege is not extended; those in which medical persons are obliged to disclose the information which they acquire by attending in their professional characters" (de Witt, 1958; Lancet, 1965a).

The report of a Joint Committee of the General Council of the Bar of England and Wales, The Law Society, and the British Medical Association, published in November, 1965, asserts that "the absence of privilege for information obtained as a result of the doctor-patient relationship can tend to defeat the ends of justice" (Medical Evidence in Courts of Law, 1965).

Two cases recently published in the Lancet show that judges might or might not press the witness to give evidence: one judge forced a psychiatrist to do so, and the dramatic climax of his conversation with the witness is retold (Lancet, 1964); another judge declared that he would not sentence psychoanalyst "X" for contempt of court, although the latter had refused to answer any questions about the patient (Lancet, 1965b).

The legal correspondent of the British Medical fournal writes:

"... the court always has a certain discretion whether 
or not to compel a witness to answer a question. It will not do so unless satisfied that the question is relevant and that compulsion is necessary in the interests of justice. Pressure is rarely put on professional men of any calling to divulge their client's secrets, but it is better that such pressure should be available to the courts than that litigants and criminals should be able to lock the truth in the mouths of their advisers" (Brit. med.F., 1964).

\section{Medical Privilege Abroad}

New Zealand, the Australian State of Victoria, and the Canadian Province of Quebec have enacted statutes creating medical privilege. The first two restrict it to civil proceedings (deWitt, 1958; Bowden, 1965), but Quebec Rev. Stat. (1941) states: "No physician may be compelled to declare what has been revealed to him in his professional character." Apart from those three jurisdictions, however, the common law of testimonial compulsion seems to be still applicable in the British Commonwealth, and also in Rhodesia and South Africa (Gordon, Turner, and Price, 1953; Mehta, 1963; Modi, 1965). Yet, in a matrimonial suit in Toronto in 1963, Mr Justice Stewart ruled that he would not order a psychiatrist to give evidence. The judge said "that it was the genius of the common law to move with the times" (Brit. med. f., 1963).

In the U.S.A., the privilege of the patient not to have the doctor testify was created by statute in 37 States and in the District of Columbia, whereas in the remaining States the doctor may be compelled to testify as in England. The statutes vary widely in scope and detail. The patient may waive privilege at any time, either by express words or by silence (deWitt, 1958; Long, 1959; Curran, 1965). Cass and Curran, writing in the Lancet, assert that the testimonial privilege "is a part of the individual's right of privacy".

“... that this right . . . should be protected by law is a new concept. It is one of the few legal principles which the United States has not borrowed directly from English Common Law. It is a uniquely American doctrine" (Cass and Curran, 1965).

However, Curran has to admit elsewhere that the American courts are not in sympathy with these statutes:

"These laws are often a means of committing substantial injustice. They are used to close the lips of a doctor who could give the court information contrary to what the patient himself is claiming." "He may bar his physician from testifying if he fears the physician will not support his fraud" (Curran, 1965).
Clinton deWitt, Professor of Law, Western Reserve University, Cleveland, is still more outspoken:

"The accumulated experience of many decades shows that the privilege has accomplished little but the concealment and suppression of the truth." "There is abundant evidence that it undermines the very foundations of justice" (deWitt, 1958).

In Germany, a doctor called as a witness has the right to refuse to give evidence or an opinion. If, however, a medical expert is appointed by the court, he is not only entitled but also under an obligation to disclose all the facts. There is no doctor-patient relationship and thus no duty of secrecy (Ponsold, 1957).

French law, on the other hand, does not only free a witness from giving evidence against his will, but by Article 378 of the Code Pénal a doctor who reveals his patient's secrets is guilty of an offence. This Article was-in 1947-interpreted as meaning "that the duty of secrecy is a general and absolute duty from which doctors cannot be freed, either by express order of the court or by the consent of the patient" (Hammelmann, 1950).

This absolute duty of silence may prove dangerous, as the following case from Marseilles shows. It was communicated to the Société de médecine légale of France and reported in the Fournal of the American Medical Association (1923) as follows:

"A young man, who was wounded in the stomach by a shot from a revolver in the hands of a friend, was conveyed to a hospital. Before operation, the wounded youth enjoined on the surgeon the strictest secrecy, irrespective of the outcome of the surgical intervention. Laparatomy revealed four perforations of the small intestine, which were sutured. Acute peritonitis developed, and the young man died. It was the duty of the surgeon to furnish a death certificate, and he entered 'peritonitis' as the cause of death. This certificate was accepted, and the body was buried. One month later, the authorities were informed of the homicide; the perpetrator of the act was arrested and confessed. The surgeon, when called as a witness, stated that, by reporting in the death certificate 'peritonitis' as the cause of death, he deemed that he was upholding the right of privileged communication and, at the same time, was telling the truth. If, after the word 'peritonitis', the surgeon had added the words 'resulting from a bullet wound of the abdomen', he would have violated the right of privileged communication".

Two decisions of French courts which apparently conflicted with professional secrecy were reported by E. H. Perreau and quoted by the F. Amer. med. Ass. (1921d). 


\section{Two Kinds of Privilege}

The expression "privileged communication" may have two quite different applications:

(1) The right or duty to be silent;

(2) The right to talk or write about the patient without fear of legal complications.

In other words, apart from meaning the right to withhold information, privilege can also indicate immunity from being sued for defamation.

Absolute privilege applies to statements in Parliament, or in a court of law where protection extends to all participants.

"A report made to a solicitor in the preparation of legal proceedings is almost certainly protected by absolute privilege" and "evidence given in the witnessbox is absolutely privileged" (Kitchin, 1941).

Qualified privilege protects a statement made by a doctor in performance of his duty, in complete good faith and without malice. It should be communicated by reasonably appropriate means and must not be published to a person who is not entitled to receive it. Kitchin advised that the practitioner should write any dangerous matter himself and should not dictate it to a secretary. The report and its envelope should also be marked "Confidential". The qualifications-or limitationsof the privilege appear sufficiently elastic. If they are all observed the doctor cannot be successfully sued, though his statements were defamatory or even false (Kitchin, 1941 ; Shartel and Plant, 1959).

\section{Venereal Diseases}

Examples of qualified privilege applied to venereal diseases will be given below.

\section{Legislation imposing Secrecy concerned with Venereal Diseases}

On July 12, 1916, the Public Health (Venereal Diseases) Regulations came into operation, and professional secrecy in respect of venereal diseases became statute law. However, the word privilege was not used. Moreover, according to a legal expert, the Acts under which the Regulations were made, did not give any power to create privilege in the proper sense of the word (Brit. med. F., 1920a).

The National Health Service (Venereal Diseases) Regulations, 1948, had the effect "to maintain the principle, originally contained in the Public Health (Venereal Diseases) Regulations, 1916, which it was necessary to revoke in consequence of the National Health Service Act, 1946, that information about persons attending venereal disease treatment centres (which are covered by the term 'hospital') shall be treated as confidential."
Legislation limiting Secrecy concerned with Venereal Diseases

The Public Health (Ophthalmia Neonatorum) Regulations, 1914, make ophthalmia neonatorum a notifiable disease. The Matrimonial Causes Act, 1937, allows a court to grant a decree of nullity if the respondent was at the time of marriage suffering from venereal disease in a communicable form and if other points had been observed.

Under Regulation 33B of the Defence (General) Regulations, 1939-inserted in Statutory Rules and Orders, 1942, and introduced in 1943-a person who infected at least two people with a venereal disease and refused treatment could be prosecuted, after due and repeated notifications to the Local Authority had proved unsuccessful. Regulation 33B expired on December 31, 1947. On July 3, 1962, Mr Richard Marsh, M.P. for Greenwich, tried unsuccessfully to restore it (Hansard).

\section{Some Important Decisions}

In 1920 a confrontation of common law with the statutory regulations occurred:

"Mrs Clara Garner... was granted a decree nisi dissolving her marriage ... on the ground of his" [her husband's] "adultery and cruelty ... The adultery was proved. The cruelty alleged consisted of the communication of syphilis by the respondent to the petitioner. Dr Salomon Kadinsky," [now Sir Stanford Cade] "of the Westminster Hospital, was called to prove that the petitioner was suffering from syphilis. The witness, before being sworn, handed a letter to the Judge from the chairman of the House Committee, stating that the hospital had adopted the national scheme for dealing with venereal disease, and enclosing a copy of the statutory regulations, one of which enjoined absolute secrecy on the medical man who attended the patient. The letter, which was read aloud by the learned Judge, drew attention to the statutory regulation that all information about any person who was treated under the scheme should be regarded as confidential."

Mr Justice McCardie-after making a few friendly references to the doctor-said "that in a Court of Justice there were even higher considerations than those which prevailed with regard to the position of medical men. He wished to say that, apart from the obligations which might be imposed on medical men by the order of his Majesty's Judges, it was desirable that there should be the most loyal observance of the confidence which was reposed in them by patients." The judge concluded with some friendly references to the medical profession in general. "On the conclusion of the 
learned Judge's remarks, Dr Kadinsky took the oath and gave evidence that the petitioner suffered from syphilis". (Garner $v$. Garner, The Times Law Reports, vol. 36, January 30, 1920, p. 196).

In $1921 \mathrm{Mr}$ Justice Horridge and Lord Mersey made similar decisions in divorce courts (Glaister, 1962), but here the petitioners were not the patients. Much medical criticism ensued (Brit. med. F., 1921a, b; F. Amer. med. Ass., 1921a, b, c; Lord Dawson of Penn, 1922; Thompson, 1936).

In 1946, in a divorce action at Birmingham Winter Assizes, $\mathrm{Mr}$ Justice Lewis ruled that secrecy in connexion with venereal disease clinics does "not justify a doctor in refusing to divulge confidential information to any named person or persons when asked by the patient so to do; and a doctor is not guilty of any breach of confidence in giving the information asked for in those circumstances." This view had the approval of Lord Merriman, the President of the Probate, Divorce and Admiralty Division.

The respondent was treated at a V.D. clinic soon after her marriage. The petitioner was examined at the same clinic and by the same doctor. After some time it was found that there was no evidence that he was suffering from the same disease. Proceedings under the Matrimonial Causes Act, 1937, were instituted. "The doctor was asked ... by the respondent to state particulars of her illness and if it was possible to say the approximate date of the commencement of that illness. Except to say that secondary syphilis was the disease, the doctor did not answer the respondent's request for the further information." A questionnaire "was sent to the doctor signed personally by the petitioner and the respondent, with the approval of the solicitors of both parties, asking for information as to the condition of the respondent." "The doctor refused to give the information, stating that he would, if subpoenaed, give his evidence in court." Mr Justice Lewis said that those particulars were vital to the success or failure of the case and implied that the doctor was not entitled to say "Go on with your case in the dark and I will tell you in court when I am subpoenaed what my conclusions are" (C. v. C., 1946, All England Law Reports, vol. 1, p. 562).

In Garner v. Garner and C. $v$. C. it was the patient herself who requested that the information should be given. The doctor refused in both cases, because of the statutory regulations, unless and until compelled by the judge.

"Mr Justice McCardie said that the statutory regulations could not override the obligation of a medical witness to give evidence. Mr Justice Lewis has extended the principle by ruling that they cannot override the doctor's obligation, when asked by his patient, to give a preliminary statement" (Brit. med. F., 1946).

Experts also assert that, if the solicitors are acting for the patient, no written authorization from him is required for a medical report.

If a solicitor applies for information about a patient other than his client and without the patient's consent, he should be advised to ask the patient's solicitor to obtain and release to him the information required. If the suggestion is not adopted, the doctor or the hospital authority will be far less vulnerable to criticism in court than if they had flatly refused to furnish the information.

Ministry of Health Circular H.M. (59) 88 deals with problems of "supply of information about hospital patients engaged in legal proceedings."

\section{Recent Observations}

Letters were received by at least three hospital administrators from a firm of solicitors who stated they were acting on behalf of a man who was appealing against an affiliation order made against him at the instance of a spinster. He had been granted legal aid to appeal, and counsel had given certain advice relative to obtaining further evidence to support the appeal. They had been instructed that the woman concerned had contracted venereal disease, and they were wondering whether the hospital records showed that she was ever treated at the hospital's clinic for this disease. If so, they asked whether the hospital could let them have the dates of treatment in writing as they stated that there would appear to be no privilege in withholding such information. They referred to the two casesGarner v. Garner and C. v. C.- described above.

The solicitors acting for one of the hospitals pointed out to the solicitors concerned in the particular case that in the two cases quoted the patient herself had asked for the information to be divulged. No such request had been forthcoming from the woman in question. They had, therefore, advised the hospitals to refuse to divulge that information without her authority or request. Nothing further was heard by them or the hospitals.

Photo-copies of the original reports on the two cases (Garner $v$. Garner and C. v. C.) can be easily obtained for one shilling each.

\section{Other Considerations limiting Secrecy con- cerned with Venereal Diseases}

The Application of Qualified Privilege Two examples show how doctors exceeded the limits of privilege:

"In Guy v. Green (Leeds Assizes, 1903), the plaintiff was awarded damages against the defendant doctor. On this occasion, a doctor who knew that a barmaid, one of his patients, suffered from syphilis, informed her 
employer and the housekeeper of the hotel. Unfortunately he did so in the hearing of one of the other barmaids. It was held that the occasion was privileged as to the employer and the housekeeper but the question of privilege in respect of the other barmaid was left to the jury. They returned a verdict for the plaintiff and awarded $£ 75$ in damages" (Polson, 1965).

The other case happened in Johannesburg: The medical adviser of a sickness benefit society took a sealed envelope containing certificates to an official of the society. As the official was not there, the doctor handed the envelope to a girl aged 14 or 15 . Before doing so he wrote on the outside of the envelope: "Foster's illness is syphilis". Foster had claimed sick pay for which he was not entitled according to the rules of the society as he suffered from a venereal disease. The doctor just wanted to explain why there was no certificate for Foster in the envelope. He was in a hurry and had no other envelope at hand. Had those words been published to the official, the occasion would have been privileged. The court regarded the action as grossly negligent but could prove no malice. A magistrate had awarded $£ 75$ in damages. The Appeal Court reduced the amount to $£ 25$ (Tothill v. Foster, 1925, South African Law Reports, Transvaal Provincial Division, pp. 857-868).

The following cases are from Hungary, Rhodesia, and the U.S.A.:

The first is copied from the Lancet, 1921: "One day during March a venereal diseases specialist, seated in the large warm-water basin in the antechamber to the steam hall of the Turkish baths at Debretzin, recognized in a young man who was about to enter the water one of his own patients who had consulted him 2 weeks previously for an extensive syphilitic sore on the penis." He had prescribed calomel ointment. He whispered to him that he must not enter the basin. The patient refused to comply. The specialist sent for the manager and told him. The rules of the public baths were explained to the patient. He "went away, and consulted another specialist, who gave him a written certificate that on that day his sore had healed, leaving only a hard infiltration. The young man sued the doctor for trespassing the medical secrecy laws, but lost his case, the court decreeing that the specialist only carried out his professional duty, being right to presume that the chancre had not healed in so short a time, and acting in the interests of the community in so doing" (Lancet, 1921).

The other four cases show that a doctor may make and disclose a wrong diagnosis and still get off scot-free:

In ex parte Rautenbach, heard in Salisbury, Rhodesia, in 1938, a doctor diagnosed venereal disease in a woman and informed her husband, but was proved wrong in the end. The husband ill-treated and deserted his wife and remained convinced that she had V.D. She appealed for leave to sue the doctor for damages for his "wrongful, unlawful, and negligent diagnosis, and also that he wrongfully, unlawfully, and negligently informed her husband that she was suffering from venereal disease." The application was refused on the ground that the harm she had suffered was due not to the diagnosis of venereal disease but to the highly unreasonable conduct of her husband. The judge inferred that her remedy, if any, was to sue for defamation (Ex parte Rautenbach, 1938, Southern Rhodesian High Court Reports, pp. 150-3; also quoted by Gordon, Turner, and Price, 1953).

In a case from Nebraska in 1920, "a physician diagnosed his patient's case as syphilis but told him he could not be sure without a Wassermann test, for which he did not have the necessary equipment. Fearing that the disease was in a highly contagious state, he told the patient to move out of the small hotel in which he was living. The next day, the physician discovered that the patient was still at the hotel and informed the hotel proprietor that the patient had a contagious disease. Consequently, the proprietor forced the patient to move. When a Wassermann test... proved negative, the patient brought an action for damages against the physician. The court said that a wrongful breach of confidence would give rise to a civil action for damages but held that in this case the closure (sic) was not wrongful, because the physician had a duty to disclose his diagnosis in order to prevent the spread of the disease" (Stetler and Moritz, 1962).

The following two cases were also heard in the U.S.A., in 1919 and 1926 respectively:

"Plaintiff's local physician sent him to defendant for examination and report. Defendant made an examination, had a blood sample tested and then wrote to the local physician reporting a diagnosis of syphilis. This diagnosis was in error. Plaintiff sued defendant for libel. The court held that the statement by defendant was privileged and the action could not be maintained."

"Plaintiff desired to embark on one of defendant's ships about to sail from Puerto Rico to the United States, but was not allowed to do so. She sought an explanation from a physician who was employed by defendant. He told her in the presence of several persons that she could not embark because she was suffering from a venereal disease. This statement was false. In an action for slander the court held that the communication was privileged and that the action could not be maintained" (Shartel and Plant, 1959).

Only one of the seven cases cited occurred in England. A legal authority asserts that decisions of foreign-or even Scottish-courts are not binding on courts in England and Wales, although they are often of valuable persuasive effect, especially when there is no precedent in this country.

Medical Privilege in the U.S.A. and Venereal Diseases The statutes creating the privilege of non-disclosure vary from State to State in the 
U.S.A. They seem to reflect local conditions. Thus, "in Michigan, in prosecutions for illegal marriage of persons sexually diseased, any physician who has attended the husband or wife for gonorrhoea or syphilis can be compelled to testify to any facts found by him from such attendance." On the other hand, "the New Mexico statute restricts the privilege, except in Workmen's Compensation cases, to any communication made with reference to any real or supposed venereal or loathsome disease" (deWitt, 1958).

\section{Other Problems of Secrecy about Venereal Diseases}

Both tracing and interviewing alleged contacts of infected patients naturally pose questions of secrecy. Methods of dealing with the problem were suggested by Circular 5/48 issued by the Ministry of Health on January 5, 1948, a few days after expiry of Regulation 33B. The follow-up of defaulters presents similar problems.

As to the reporting of established V.D. cases, general opinion-in this country anyway-seems to be against it. However, a "Report on Venereal Diseases" by the Medical Advisory Committee (Scotland), recommended in 1944 that legislation be devised to require notification of every established case of venereal disease in code.

An American authority went further: Reporting of cases by numbers or initials rather than by names of the patients would "defeat the very purpose of venereal disease reporting as the first step in the epidemiological control process" (Tuerck, 1964).

Opinions differ whether the patient should be called by name or number: "At the clinic he is referred to by number only". So says a booklet on "Venereal Disease Service", prepared by The Standing Medical Advisory Committee for the Central Health Services Council and the Minister of Health, published in July, 1962. However, "a survey carried out at the Middlesex Hospital indicates that the vast majority of patients of both sexes ... prefer to be known and called by their names rather than by numbers" (Catterall and Seale, 1965).

\section{Summary and Conclusions}

The obligation of disclosure often overrules the duty of silence. The chief instances are as follows:

(a) The doctor can be ordered to give evidence in court. This testimonial compulsion applies to Great Britain but does not obtain in a number of other countries, (b) Certain statutes require the doctor to make a report or notification.

(c) The doctor should convey information to a person with a corresponding duty or interest to receive it.

(d) The duty to the public may override the doctor's obligation to preserve confidence.

Venereal diseases present special problems of conflict between the patient's needs and the public interest.

Two important court decisions and their misapplication are quoted. Seven-mostly foreigncases show that qualified privilege is likely to protect the doctor's statements if he follows a few certain rules.

The problems of medical secrecy are complicated, and there is no unanimity about them. They have received scant attention in text-books, and ignorance of them is not confined to medical men.

The doctor must know when there is "a time to keep silence, and a time to speak" (Ecclesiates, 3, vii).

\section{REFERENCES}

Bowden, K. M. (1965). "Forensic Medicine", 2nd ed., p. 26. The Jacaranda Press, Brisbane.

Cass, L. J., and Curran, W. J. (1965). Lancet, 2, 783.

Catterall, R. D., and Seale, J. R. (1965). Brit. med. F., $1,1305$.

Curran, W. J. (1965). "Tracy's The Doctor as a Witness", 2nd ed., pp. 36-40, 46-7, 50. Saunders, Philadelphia and London.

Dawson of Penn (1922). Lancet, 1, 619.

deWitt, C. (1958), "Privileged Communications between Physician and Patient", pp. 11-13, 18, 36-7,77, 150, 466-7. Thomas, Springfield, Ill.

Glaister, J. (1962). "Medical Jurisprudence and Toxicology", 11th ed., p. 50 . Livingstone, Edinburgh and London.

Gordon, I., Turner, R., and Price, T. W. (1953). "Medical Jurisprudence", 3rd ed., pp. 50-5, 188, 318. Livingstone, Edinburgh and London.

Hammelmann, H. A. (1950). The Canadian Bar Review, 28, 750-8.

Kitchin, D. H. (1941). "Law for the Medical Practitioner", pp. 54-5, 156-7. Eyre and Spottiswoode, London.

Levitt, W. M. (1953). In "Modern Trends in Forensic Medicine", ed. K. Simpson, p. 249. Butterworths, London.

Long, R. H. (1959). "The Physician and the Law", 2nd ed., p. 277. Appleton-Century-Crofts, New York.

Mehta, H. S. (1963). "Medical Law and Ethics in India", p. 378. The Bombay Samachar Private Ltd., Bombay.

Modi, N. J. (1965). "Modi's Textbook of Medical Jurisprudence and Toxicology", 15th ed., p. 17. Tripathi, Bombay. 
Polson, C. J. (1965). "The Essentials of Forensic Medicine", 2nd ed., pp. 527-8. Pergamon Press, Oxford.

Ponsold, A. (1957). "Lehrbuch der Gerichtlichen Medizin", 2nd ed., pp. 31-2. Thieme, Stuttgart.

Shartel, B., and Plant, M. L. (1959). "The Law of Medical Practice", pp. 177-8. Thomas, Springfield, Ill.

Simpson, K. (1962). "A Doctor's Guide to Court", pp. 133-5. Butterworths, London.

(1964). "Forensic Medicine", 5th ed., pp. 230-1. Arnold, London.

Speller, S. R. (1965). "Law Relating to Hospitals and Kindred Institutions", 4th ed., pp. 302-10. Lewis, London.

Stetler, C. J., and Moritz, A. R. (1962), "Doctor and Patient and the Law", 4th ed., p. 271. Mosby, St. Louis.

Thompson, W. Derwent R. (1936). Brit. F. vener. Dis., $12,88$.

Tuerck, E. F. (1964). "Legal Basis for Syphilis Control". Proceedings of the World Forum on Syphilis and other Treponematoses, pp. 85-7. U.S. Department of Health, Education and Welfare, Atlanta, Georgia.

Brit. med.F. (1920a). 1, 135-6: "Medical Professional Privilege".

(1920b). 2, Suppl. 9-11: "Professional Secrecy". (1921a). 1, 904: "Professional Secrecy in Courts of Law".

(1921b). 2, 17-18: "Professional Secrecy".

- (1946). 1, 778: "Secrecy in Judicial Proceedings". (1963). 1, 1615-16: "Psychiatrist Excused from Giving Evidence".

- (1964). 2, 955-6: "Medical Professional Privilege".

HANSARD (1962). 2, 5th series, vol. 662, 291-4.

7. Amer. med. Ass. (1921a). 77, 298: "Professional Secrecy again in the Courts".

(1921b). 77, 388: "Professional Secrecy".

- (1921c). 77, 632: "Professional Secrecy".

- (1921d). 77, 738: "Professional Secrecy and the Courts".

- (1923). 80, 1787-8: "Privileged Communication and Declaration of Death".

Lancet (1921). 1, 822: "An Interesting Case of Medical Secrecy".

- (1964). 2, 145: "The Psychiatrist as Witness". (1965a). 2, 777-8: "Medical Privilege in English Law".

- (1965b). 2, 785-6: "Psychoanalyst subpoenaed".

Medical Evidence in Courts of LAW (1965). p. 14. B.M.A.

Ministry of Health Circular (1948). "Venereal Diseases. Expiry of Defence Regulation 33B". 5/48.

-_. "National Health Service", H.M. (59) 88.

Report on Venereal Diseases. Medical Advisory Committee (Scotland), (1944), p. 19. H.M.S.O.

Venereal Disease Service. The Standing Medical Advisory Committee for the Central Health Services Council and the Minister of Health (1962). p. 1. M.O.H.
STATUTES

Code Pénal, Article 378. "Codes Français" (1901), by H. F. Rivière, 29th ed., p. 68.

The Matrimonial Causes Act, 1937, s. 7 (1) c.

National Health Service. The National Health Service (Venereal Diseases) Regulations, 1948 (Explanatory Note). H.M.S.O.

The Public Health (Ophthalmia Neonatorum) Regulations, 1914. H.M.S.O.

The Public Health (Venereal Diseases) Regulations, 1916, pp. 14-16. H.M.S.O.

Quebec Rev. Stat. 1941, 264, 60, 2.

\section{Cases Cited}

C. v. C. 1946, All England Law Reports, vol. 1, p. 562.

Garner $v$. Garner 1920, Times Law Reports, vol. 36, p. 196.

Ex Parte Rautenbach 1938, Southern Rhodesian High Court Reports, p. 150.

Tothill v. Foster 1925, South African Law Reports, Transvaal Provincial Division, p. 857.

\section{Le secret professionnel concernant plus spécialement les maladies vénériennes. \\ RÉSUMÉ}

L'obligation de divulguer passe outre bien souvent au devoir de rester silencieux. Les principales circonstances sont les suivantes:

(a) Le médecin peut recevoir l'ordre de déposer en Cour. L'obligation de témoigner a force de loi en Grande Bretagne, mais cette obligation n'existe pas dans un certain nombre d'autres pays.

(b) Certaines lois exigent que les médecins produisent des rapports ou des notifications.

(c) Le médecin doit donner des renseignements à une personne qui remplit une fonction analogue et qui est en droit de les recevoir.

(d) Le devoir envers le public peut avoir plus d'importance que n'a l'obligation du médecin de garder pour lui les confidences qui lui sont confiées. Les maladies vénériennes présentent des problèmes spéciaux de conflit entre les exigences du malade et l'intérêt public.

Deux décisions importantes de la Cour et leur mauvaise interprétation sont citées. Sept cas, la plupart étant d'origine étrangère, montrent que le privilège restreint peut probablement protéger les déclarations du médecin qui suivrait certaines règles.

Les problèmes concernant le secret professionnel sont compliqués et il n'existe aucune unanimité à leur sujet. Ils ont reçu très peu de mention dans les manuels et les médecins ne sont pas les seuls à ne pas les connaître.

Le médecin doit savoir quand il y a "un temps pour se taire, et un temps pour parler" (Qo, 3, vii). 